\title{
Copper, Iron and Zinc concentrations of tobacco leaves and ready-to-use snuff products on sale in Imo State Southeastern Nigeria.
}

\section{*11NNOROM, INNOCENT CHIDI}

\author{
Analytical/Environmental Chemistry Unit, Department of Pure and Industrial Chemistry, Abia State University, Uturu, Abia State, \\ Nigeria \\ (E-mail: chidiabsu@yahoo.co.uk)
}

\begin{abstract}
This paper reports the results of the determination of the concentrations of $\mathrm{Zn}, \mathrm{Cu}$, and $\mathrm{Fe}$ in tobacco leaves and snuff products on sale in some regional markets in Imo State, Southeastern Nigeria. The samples were ashed at $550^{\circ} \mathrm{C}$, mineralized with acid and the metal concentrations measured using flame atomic absorption spectrophotometer. The mean metal concentrations are $843 \pm 46 \mathrm{mg} \mathrm{kg}^{-1}$ for Fe, $79 \pm 4 \mathrm{mg} \mathrm{kg}^{-1}$ for $\mathrm{Zn}$, and 22 $\pm 2 \mathrm{mg} \mathrm{kg}^{-1}$ for $\mathrm{Cu}$ in snuff samples and; $951 \pm 78 \mathrm{mg} \mathrm{kg}^{-1}$ for $\mathrm{Fe}, 83 \pm 2 \mathrm{mg} \mathrm{kg}^{-1}$ for Zn, and $24 \pm 2 \mathrm{mg} \mathrm{kg}^{-1}$ for $\mathrm{Cu}$ in tobacco leaves. Comparably, higher metal concentrations were obtained in tobacco leaves than in the snuff products, and the metal concentrations varied according to the regional markets from where they were purchased. The results of this study indicate that snuff products could constitute trace metal exposure routes to users. (C) JASEM
\end{abstract}

http://dx.doi.org/10.4314/jasem/v19i3.16

KEYWORDS: snuff; trace metals; tobacco; toxicology; Nigeria

\section{INTRODUCTION}

The global consumption of tobacco products, especially cigarette, has been on the increase. Tobacco is an herbaceous plant that contains nicotine and is native to North and South America, Australia, southwest Africa, and the South Pacific. Tobacco stands for any of various plants of the genus Nicotiana of the nightshade family (Solanaceae) as well as the leaves of several of these plants, which are processed for smoking, chewing or snuffing (Ali et al., 2006). Nicotiana tabacum is the cultivated tobacco plant most commonly used to make commercial tobacco products. Nicotine [3-(1-methyl2-pyrrolidinyl)-pyridine, $\left.\mathrm{C}_{10} \mathrm{H}_{14} \mathrm{~N}_{2}\right]$ is a highly toxic liquid alkaloid found naturally in several plant species, including $N$. tabacum, and is the key addictive component of tobacco products.

Nicotine is used to make consumer products such as cigarettes, cigars, pipe tobacco, chewing tobacco, and snuff. Cigarettes represent small rolls of cut tobacco wrapped in paper for smoking while cigars consist of rolls of tobacco leaves for smoking. The use of oral and nasal Smokeless Tobacco Products (STPs) including snuff, is common worldwide, but is highest on the Indian subcontinent (Ayo-Yusuf and Connolly, 2011).

STPs are pulverized or shredded tobacco which are chewed or placed between cheek and gum or inhaled in small pinches of about $0.1 \mathrm{~g}$ amounts through the nostrils. That means that STPs do not have to be lit as opposed to other tobacco products (Ali et al., 2006). Snuff usually consists of tobacco that is ground and mixed with salts, flavors (such as peppermint oil, eucalyptus oil, menthol, or fruit extracts) and moisturizing agents. Snuff is "snuffed" or inhaled (insufflated) through the nose either directly from the fingers or by using specially made aids referred to as "snuffing" devices.

The role of tobacco and tobacco smoke as causative agents for a wide variety of cancers, cardiovascular and respiratory diseases has been well established (IARC, 1986). To date, more than 3000 chemicals have been identified and isolated from tobacco (Roberts, 1998; WHO, 2004). More than 1000 of the chemical constituents present in unburnt "whole" tobacco are also present as emissions in tobacco smoke (Hammond and O'Connor, 2008). The extent to which smokeless tobacco endangers human health is an ongoing subject of debate. There has been increasing health concern over the consumption of STPs (Evangelou et al., 2006). The most common adverse effect of snuff is the lesion in the oral cavity. Snuff with high $\mathrm{pH}$ and nicotine content produce more damage. The lesions are mostly reversible when snuff use is stopped.

To a small extent, heavy metals enter the body through food, drinking water and air. As trace elements, some heavy metals e.g. $\mathrm{Cu}, \mathrm{Zn}$, etc are essential to human body. However, at higher concentrations, they can lead to poisoning. Heavy 
metals are dangerous because they tend to bioacummulate. Tobacco products including snuff has been shown to contain some heavy metals and Interest in the trace metal concentrations of tobacco products have been on the increase (Mishra and Shaikh, 1985, 1986; Mishra et al., 1986; Shaikh et al. 1992; Shaikh et al., 2002; Addo et al. 2008; Dhaware et al. 2009; Pappas et al. (2008). Other studies have also investigated other toxic components of tobacco especially the tobacco specific nitrosamines (TSNA) (McNeill et al., 2006; Pakhale and Maru, 1998). Toxic metals in smokeless tobacco products have been less extensively studied (Pappas et al., 2008).

Studies into the trace metal contents of tobacco products have been focusing more on cigarettes (Zawadska et al. 1989; Jung et al., 1998; Spiff et al., 1999; Shaikh et a., 2002; Nnorom et al., 2005; Pappas et al., 2007) and cigarette/tobacco smoke (Mishra and Shaikh, 1985; Mishra et al., 1986; Schneider and Krivan, 1993; Shaikh et al. 1992; Shaikh et al, 2002; Pakhale and Maru, 1998; Pappas et al., 2007; Hammond and O'Connor 2008). Studies of snuff products have also been increasing in recent times (Mishra and Shaikh 1986; Brunnemann and Hoffmann, 2002; Addo et al., 2008; Pappas et al., 2008). Toxic metals in tobacco products are either from the tobacco leaves or as contaminants introduced during either the pre-harvesting treatment (e.g. from fertilizers and pesticides) or from the postharvest additives (e.g. from preservatives) (Iskander, 1986).

Relevant data about trace metal contamination of tobacco leaves and the processed snuff products from Nigeria and the attendant health implications of human exposure to metal contaminants in these products are still limited and further studies need to be conducted. The objective of this study is to determine the concentrations of $\mathrm{Fe}, \mathrm{Zn}$ and $\mathrm{Cu}$ in tobacco leaves and locally processed snuff products marketed in Imo State, southeastern Nigeria.

\section{MATERIALS AND METHODS}

Sample collection: Thirty samples of tobacco leaves and thirty locally processed snuff samples marketed in some regional markets in six Local Government Areas (LGAs) of Imo State, Southeastern Nigeria were used in this study. The tobacco leaves and snuff samples were purchased from local snuff sellers in different market locations in six LGAs in Imo State in July 2008. The LGAs are Owerri Municipal LGA, Owerri North LGA, Owerri West LGA, Okigwe LGA, Ikeduru LGA, and Mbano LGA. The markets are New Market Owerri, Afor Obazu Mbieri, Ekenta Ikeduru, Nkwo Market Nekede, Afor Ogbe Market,
Abakpa Market Okigwe, Orie Mbieri Market, Eke Obinze Market, Eke-Atta Ikeduru, Afor Egbu Market, Afor Emmi Market, Eke Okigwe Market, Eke Onunwa Market, Nkwo Irete Market, Nkwo Orodo Market Owerri, Orieukwu Umuguma Market, Avefe Market Owerri West, and Orieagu Mbano.

One foreign brand of processed snuff was also purchased and investigated. On purchase, the samples were adequately labeled and transported to the laboratory.

Sample analysis: $1.0 \mathrm{~g}$ of the sample was placed in a porcelain crucible and dry-ashed in a muffle furnace at $550^{\circ} \mathrm{C}$ for about 8 hours (until a white or grey ash residue was obtained), cooled in a desiccator and then wet digested. The wet digestion was performed by adding $5 \mathrm{ml}$ of conc. $\mathrm{HNO}_{3}(69 \%$, BDH Laboratory Supplies, Poole, England) to each sample and heating to near dryness on a heating mantle. Where necessary, additional acid was added, and heating continued until evolution of white fumes. The solution was allowed to cool, then filtered into a calibrated flask (10ml) and made up to volume with deionized water. Blanks were inserted at $10 \%$ insertion rate. The $\mathrm{Fe}, \mathrm{Zn}$, and $\mathrm{Cu}$ concentrations were determined using Buck 211 Atomic Absorption Spectrophotometer. The following quality assurance procedures and precautions were applied to ensure reliability of results: Samples were carefully handled to avoid contamination; all chemicals used were of analytical grade; all plastic-and-glassware were washed, rinsed severally with tap water, and then soaked in 5\% HNO3 (69\%, BDH, Poole, England) solution for a minimum of 24 hours. They were rinsed severally with deionized water before use.

\section{RESULTS AND DISCUSSION}

The $\mathrm{Fe}, \mathrm{Zn}$ and $\mathrm{Cu}$ concentrations of the tobacco leaves and snuff samples investigated are presented in Figures 1-3 respectively. The only foreign brand studied is indicated as FB (Foreign Brand) in Figures 1-3. Comparisons of the mean metal concentrations of the samples according to the regional markets are presented in Figure 4 for Fe, Figure 5 for $\mathrm{Zn}$ and Figure 6 for the $\mathrm{Cu}$ concentrations. The summary of metal concentrations for samples investigated is presented in Table 1. Comparably, higher metal concentrations were obtained in tobacco leaves than in the processed snuff products (Figure 1-3; Table 1). In the production of nasal snuffs, tobaccos are blended and milled in a high speed mill to produce very fine powder. The powder is moistened, fermented and matured in a cool storage room for about three to four weeks. After final blending, flavorings are added as well as moistening agents 
such as glycerol or paraffin oil (Ali et al., 2006). Consequently the use of these additives which naturally do not contain significant levels of these metals in the snuff products may contribute to the lowering of the metal concentrations in the finished product.

The Fe concentration of the only foreign brand (FB) investigated (1961 $\mathrm{mg} \mathrm{kg}^{-1}$ ) was more than twice the mean Fe concentration of the locally processed snuff (843 $\mathrm{mg} \mathrm{kg}^{-1}$; range, $678-919 \mathrm{mg} \mathrm{kg}^{-1}$ ). The $\mathrm{Zn}$ and $\mathrm{Cu}$ concentrations of the FB (indicated as FB on Figures 2 and 3 respectively) were comparable to the data obtained for the locally processed snuff products. The $\mathrm{Zn}$ concentration of the FB was however moderately lower $\left(67 \mathrm{mg} \mathrm{kg}^{-1}\right)$ than the mean value for the locally processed snuff product (79 $\mathrm{mg} \mathrm{kg}^{-1}$; range, 67-84 $\mathrm{mg} \mathrm{kg}^{-1}$ ) whereas the $\mathrm{Cu}$ concentration of the FB was slightly higher $(25 \mathrm{mg}$ $\mathrm{kg}^{-1}$ for $\mathrm{FB}$ and $22 \mathrm{mg} \mathrm{kg}^{-1}$ for local snuff products).

Wider variations were obtained in the $\mathrm{Fe}$ concentrations of both the tobacco leaves and the finished snuff products as indicated by the very wide range and high standard deviation for Fe compared to the other metals (Table 1).

As shown in Figures 4-6, moderate variations exists in the contents of trace metals for both tobacco leaves and snuff samples according to the regional markets sampled. The mean metal concentrations obtained in samples from different regions (LGAs) vary thus: the mean metal concentration of tobacco leaves according to LGAs ranged from $906 \pm 58 \mathrm{mg} \mathrm{kg}^{-1}$ (Mbano LGA) to $1008 \pm 36 \mathrm{mg} \mathrm{kg}^{-1}$ (Okigwe LGA) for Fe; $23 \pm 3 \mathrm{mg} \mathrm{kg}^{-1}$ (Ikeduru LGA) to $26 \pm 3 \mathrm{mg}$ $\mathrm{kg}^{-1}$ (Owerri Municipal LGA) for Cu and $82 \pm 1 \mathrm{mg}$ $\mathrm{kg}^{-1}$ (Owerri West LGA) to $84 \pm 2 \mathrm{mg} \mathrm{kg}^{-1}$ (Owerri Municipal LGA) for Zn (Figures 3-5).

For snuff products, the mean concentration according to LGAs ranged from $818 \pm 96 \mathrm{mg} \mathrm{kg}^{-1}$ (Mbano LGA) to $855 \pm 39 \mathrm{mg} \mathrm{kg}^{-1}$ (Owerri West LGA) for Fe; $20 \pm 4 \mathrm{mg} \mathrm{kg}^{-1}$ (Ikeduru LGA) to $23 \pm 2 \mathrm{mg} \mathrm{kg}^{-1}$ (Owerri Municipal LGA) for $\mathrm{Cu}$ and $76 \pm 3 \mathrm{mg} \mathrm{kg}^{-1}$ (Ikeduru LGA) to $81 \pm 2 \mathrm{mg} \mathrm{kg}^{-1}$ (Okigwe LGA) for $\mathrm{Zn}$ (Figures 3-5). The $\mathrm{Fe}, \mathrm{Zn}$ and $\mathrm{Cu}$ concentrations in the foreign brand (English snuff) investigated were $1961 \mathrm{mg} \mathrm{kg}^{-1}, 67 \mathrm{mg} \mathrm{kg}^{-1}$ and $25 \mathrm{mg} \mathrm{kg}^{-1}$ respectively (Figures 1-3: indicated as FB). This indicates that the foreign brand contained much higher $\mathrm{Fe}$ concentration but lower $\mathrm{Zn}$ concentration. Various studies have shown tobacco to be a rich source of heavy metals. The occurrence of metals in tobacco is largely attributed to the growth and cultivation of tobacco, as tobacco is known to readily accumulate metals from underlying soil (Schneider and Krivan, 1993; Golia et a., 2007; Tso, 2011). Consequently, the metal content of tobacco reflects the metal contents of the soil and therefore the mineral composition of the bedrock from which the soil was derived. The use of chemicals in the form of fertilizers, herbicides etc in the cultivation of tobacco may also contribute to the metal load of the soil and subsequently, the tobacco plant. Pakhale and Maru (1998) observed that plant variety, cultivation, curing methods, and designs of the smoking products (including wrapper and the presence/absence of filters differing in efficiencies) are factors that influence the formation and yields/levels of toxic chemicals in tobacco and tobacco smoke (both mainstream smoke (MS) as well as side-stream smoke.

Tobacco constituents are also modified during the curing process. For instance, tobacco specific nitrosamines (TSNAs) form primarily during the curing process and levels vary according to the curing method (Hammond and O'Connor, 2008). In fact, Pakhale and Maru (1998) observed that besides differences in plant variety and cultivation, a possible reason for significant difference in the levels of alkaloids in tobacco may be curing methods, such as sun-/air-drying of bidi/chutta tobacco while fluecuring for cigarette tobacco. N-nitrosamines are considered major contributors to the carcinogenic activity of oral snuff (Brunnemann et al., 2002). Studies also noted that flue-cured tobacco contains relatively high levels of sugars naturally present in the tobacco, produced from tobacco starch during the flue-curing process (Leffingwell, 1999; Baker et al., 2004).

The summary of metal concentrations in the tobacco leaves studied was $951 \pm 78 \mathrm{mg} \mathrm{kg}^{-1}$ (range, 834 $1164 \mathrm{mg} \mathrm{kg}^{-1}$ : median $961 \mathrm{mg} \mathrm{kg}^{-1}$ ) for $\mathrm{Fe} ; 83 \pm 2 \mathrm{mg}$ $\mathrm{kg}^{-1}$ (range, $79-87 \mathrm{mg} \mathrm{kg}^{-1}$ : median $83 \mathrm{mg} \mathrm{kg}^{-1}$ ) for $\mathrm{Zn}$; and $24 \pm 2 \mathrm{mg} \mathrm{kg}^{-1}$ (range, $21-29 \mathrm{mg} \mathrm{kg}^{-1}$ : median $24 \mathrm{mg} \mathrm{kg}^{-1}$ ) for $\mathrm{Cu}$ (Table 1). The summary of metal concentrations in the snuff samples was 843 $\pm 46 \mathrm{mg} \mathrm{kg}^{-1}$ (678 - $919 \mathrm{mg} \mathrm{kg}^{-1}$; median $843 \mathrm{mg} \mathrm{kg}$ $\left.{ }^{1}\right)$ for $\mathrm{Fe} ; 79 \pm 4 \mathrm{mg} \mathrm{kg}^{-1}\left(67-84 \mathrm{mg} \mathrm{kg}^{-1}\right.$ : median 79 $\left.\mathrm{mg} \mathrm{kg}^{-1}\right)$ for $\mathrm{Zn}$; and $22 \pm 2 \mathrm{mg} \mathrm{kg}^{-1}\left(16-27 \mathrm{mg} \mathrm{kg}^{-1}\right.$ : median $22 \mathrm{mg} \mathrm{kg}^{-1}$ ) for $\mathrm{Cu}$ (Table 1). Based on the results of this study as reflected in the mean concentrations (Table 1), the trace metals contents of tobacco leaves and snuff products were arranged in the following decreasing order: $\mathrm{Fe}>>\mathrm{Zn}>\mathrm{Cu}$.

Toxicological Concerns of metals in tobacco: Literature abound with studies showing that the consumption of tobacco products by both smoking 
and non-smoking ways affect the health of users directly as well as non-smokers via passive smoking (Stephens et al., 2005; Galazyn-Sidorczuk et al., 2008,). A significantly increased risk for oesophageal and pancreatic cancer has been associated with oral snuff use in studies undertaken in the USA and northern Europe (Boffetta et al. 2008). Snuff inhalation has also been reported to be associated with nasal sinus and nasopharyngeal cancer in some parts of Africa (Feng et al. 2009). Tobacco use kills more than 5 million people per year and it is responsible for 1 in 10 adult deaths (WHO 2011). Among the five greatest risk factors for mortality, it is the single most preventable cause of death (WHO 2011). Studies have identified tobacco smoking as one of the significant sources of toxic metals in both human body and environment (Schneider and Krivan 1993; Verma et al., 2010). While the harmful health effects of carbon monoxide, nicotine, tar, irritants and other noxious gases that are present in tobacco smoke are well known, those due to heavy metals and other toxic mineral elements in tobacco smoke are not sufficiently emphasized (Chiba and Masironi, 1992). Studies have observed that users of STPs including snuff face no known cancer risk to the lungs but more of a risk in the oral region than smokers, and have a greater cancer risk than people who do not use any tobacco products (Boffetta et al., 2008). This is because the primary harm from smoking comes from the smoke itself (Phillips and Heavner, 2009). Consequently, snuff has been proposed as a way of reducing harm from tobacco (Phillips and Heavner, 2009). Unlike tobacco smoke, snuff is free of tar and harmful gases such as carbon monoxide and nitrogen oxides. Since it cannot be inhaled into the lungs, there is no risk of lung cancer, bronchitis, and emphysema (Russell et al. 1981).

From toxicological and environmental point of view, the determination of toxic metals in consumer products such as snuff and the raw materials has promoted interest. This is because the use of these products may be a route for human exposure to potentially toxic metals. Zinc is essential for biological functions of all living matter. Zinc is necessary for growth, appetite, testicular maturation, skin integrity, mental activity, wound healing and immunocompetence. Zinc is required for the metabolic activities of over 70 metalloenzymes (Abdel-Mageed and Oehme, 1990). Even though zinc is an essential requirement for a healthy body, excess zinc can be harmful, and cause zinc toxicity. Excessive absorption of zinc can suppress copper and iron absorption (Fosmire, 1990). Zinc is considered to be relatively nontoxic, particularly if taken orally. However, manifestations of overt toxicity symptoms (nausea, vomiting, epigastric pain, lethargy, and fatigue) will occur with extremely high zinc intakes (Fosmire, 1990).

Copper is known to be an essential nutrient for human beings, but a Recommended Dietary Allowance has not yet been established (Turnlund, 1988). A safe and adequate range of intake was established in 1980 for copper with a range of 2 to 3 mg/day (Turnlund, 1988). Again, measurements of the dietary requirements for copper in adult men have shown the requirement to range from about 1.5 to 2.0 mg daily (Sandstead, 1982). Persons who consume diets high in zinc and low in protein are at risk of copper deficiency. High intakes of sources of dietary fiber apparently increase the dietary requirement for copper (Sandstead, 1982). Dietary factors that may affect the bioavailability of copper include the levels of copper, zinc, and molybdenum in the diet; iron deficiency; ascorbic acid intake; intake of carbohydrates, including fructose, glucose, and starch; and fiber and phytate intakes (Turnlund, 1988).

Comparison with Literature and review of Toxicological Concerns: Though studies of metal concentrations in snuff are limited, various studies of other tobacco related products have reported wide variation of heavy metals in cigarettes and other tobacco products (Elinder et al., 1983; Zawadska et al., 1989; Jung et al., 1998; Spiff et al., 1999; Ebisike et al., 2004; Nnorom et al., 2005; Pappas et al., 2007; 2008; Ajab et al., 2008; Iwegbue et al., 2009). Available literature indicates a detailed study of metal concentrations in tobacco products in use in India, including cigarette, cigars, biri, chewing tobacco, and snuff (Mishra and Shaikh, 1983; 1986; Mishra et al., 1986; Shaikh et al., 2002; Verma et al., 2010). Compared with documented studies of heavy metals in snuff products (Table 2), it was shown that the metal concentrations in the present study were similar to values reported in literature for tobacco and snuff products (Mishra and Shaikh, 1983; Mishra and Shaikh, 1986; Mishra et al., 1986; Shaikh et a., 2002; Verma et al., 2010). However, Jung et al., (1998) reported an average values of $7.7 \mathrm{mg} \mathrm{kg}^{-1}$ for $\mathrm{Cu}$, and $39 \mathrm{mg} \mathrm{kg}^{-1}$ (range, 35 to $46 \mathrm{mg} \mathrm{kg}^{-1}$ ) for $\mathrm{Zn}$ in Korean cigarettes; and $13 \mathrm{mg} \mathrm{kg}^{-1}$ for $\mathrm{Cu}$, and $31.9 \mathrm{mg} \mathrm{kg}^{-1}$ (27 to $37 \mathrm{mg} \mathrm{kg}^{-1} \mathrm{Zn}$ ) for $\mathrm{Zn}$ in cigarettes from the United Kingdom. Mussalo-Rauhamaa et al., (1986) reported that $\mathrm{Cu}$ in filter cigarette tobacco sampled from Finland between 1960 - 1980s averaged $16 \mathrm{mg}$ $\mathrm{kg}^{-1}$, with a range of $9.2-18 \mathrm{mg} \mathrm{kg}^{-1}$. Other studies have also reported elevated $\mathrm{Zn}$ concentrations in tobacco from India (77-180 $\mathrm{mg} \mathrm{kg}^{-1}$ ) and America (15-31 mg kg-1) (Iskander, 1992) (4.1-54 mg kg-1). Nada et al. (1999) studied cigarette components 
(tobacco, paper, ash) of two brands of cigarette and reported in the tobacco samples elevated Fe (range: $\left.7859 \pm 79 \mathrm{mg} \mathrm{kg}^{-1}-2864 \pm 29 \mathrm{mg} \mathrm{kg}^{-1}\right)$ and $\mathrm{Zn}(180 \pm 5$ $\mathrm{mg} \mathrm{kg}^{-1}-77 \pm 2 \mathrm{mg} \mathrm{kg}^{-1}$ ) concentrations. Nada et al. (1999) suggested that the high concentrations of $\mathrm{Fe}$ and $\mathrm{Zn}$ among other metals determined may suggest that cigarette components are contaminated by dust and air particulate during shipping and aging of the raw materials or during the manufacturing process.

Conclusion: The major objective of this study was to investigate the concentrations of $\mathrm{Fe}, \mathrm{Zn}$ and $\mathrm{Cu}$ in tobacco leaves and snuff products. Elevated Fe, Zn and $\mathrm{Cu}$ concentrations were observed in tobacco leaves and snuff samples marketed in selected regional markets in Imo state Nigeria. Trace metal concentrations in tobacco and snuff are related to the source: the regional markets. Higher concentrations of these metals were found in tobacco leaves compared to the snuff samples. These data suggest that local processing activities which may include the addition of additives which may not contain these metals in significant concentrations results in the lowering of the metal concentrations in the finished snuff products. Knowledge of trace metal contents of products such as tobacco and snuff which are regularly used by the aged and elderly in southeastern Nigeria provides important information to the evaluation of trace metals available to the users who are highly vulnerable.

This study shows that the use of snuff marketed in Imo State, Nigeria could constitute a significant contributor of heavy metals intake in the consumers. The present work has demonstrated the need of establishing a national regulatory framework for the levels of trace metals in these products. There is also need for further studies to ascertain the forms of these metals in the tobacco products and to evaluate the potential risk to human from the use of these products. In snuff, the main exposure routes are ingestion and inhalation depending on the mode of use: oral application or sniffing. There is also minute risk of passive exposure in family members including the vulnerable groups: children, the aged and pregnant women. It is hoped that these results could serve as a guide in decision making and formulation of policies on the local production/preparation and consumption of snuff.

Table 1. Summary of trace metal content of tobacco leaves and snuff products $\left(\mathrm{mg} \mathrm{kg}^{-1}\right)$

\begin{tabular}{lllllll}
\hline & \multicolumn{3}{l}{ Tobacco leaves } & \multicolumn{2}{l}{ Snuff } \\
\cline { 2 - 7 } Minimum value & $\mathrm{Fe}$ & $\mathrm{Zn}$ & $\mathrm{Cu}$ & $\mathrm{Fe}$ & $\mathrm{Zn}$ & $\mathrm{Cu}$ \\
Maximum value & 1164 & 79 & 21 & 678 & 67 & 16 \\
Mean & 951 & 83 & 29 & 919 & 84 & 27 \\
Standard deviation & 78 & 2 & 2 & 843 & 79 & 22 \\
Geometric mean & 946 & 83 & 24 & 84 & 4 & 2 \\
Median & 961 & 83 & 24 & 843 & 78 & 21 \\
Standard error & 14 & 0.3 & 0.4 & 8.4 & 0.7 & 22 \\
\hline
\end{tabular}

$\underline{\text { Table 2. Comparison of results of present study with literature }\left(\mathrm{mg} \mathrm{kg}^{-1}\right)}$

\begin{tabular}{lllll}
\hline & Fe & Zn & Cu & References \\
\hline $\begin{array}{l}\text { Tobacco } \\
\text { (chewing tobacco) }\end{array}$ & 1565 & 19 & - & Mishra and Shaikh, 1986 \\
& 1050 & 20 & 11 & Mishra et al, 1986 \\
& 110 & 28 & 12 & Shaikh et al, 2002 \\
& $1686-1720$ & $12-25$ & - & Mishra and Shaikh, 1983 \\
& 853 & 56 & 42 & Verma et al, 2010 \\
& 951 & 83 & 24 & Present study \\
Snuff & 2323 & 46 & - & Mishra and Shaikh, 1986 \\
& 2090 & 43 & 21 & Mishra et al, 1986 \\
& - & 42 & 28 & Shaikh et al, 2002 \\
& 2972 & 37 & 16 & Verma et al, 2010 \\
& 843 & 79 & 22 & Present study \\
\hline
\end{tabular}




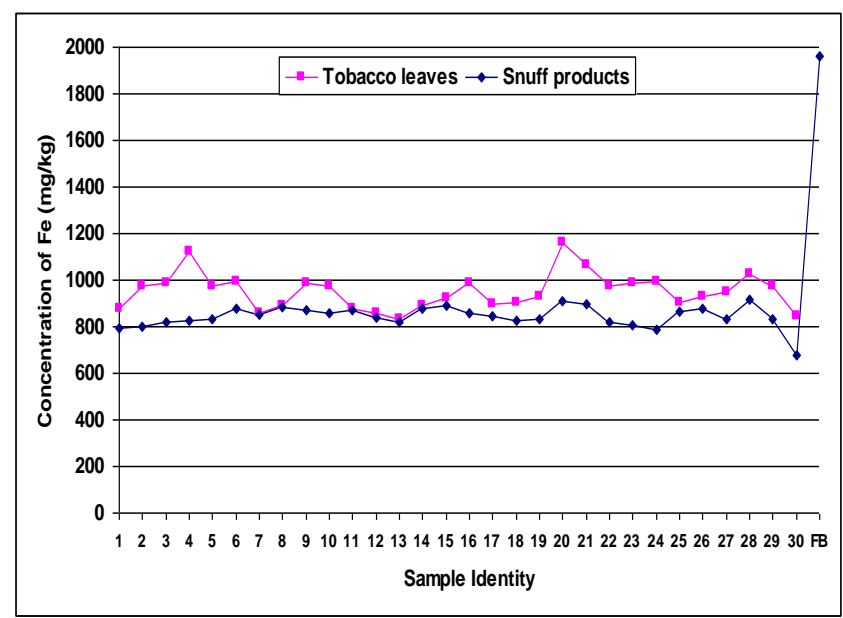

Fig 1. Fe concentrations in tobacco leaves and snuff samples

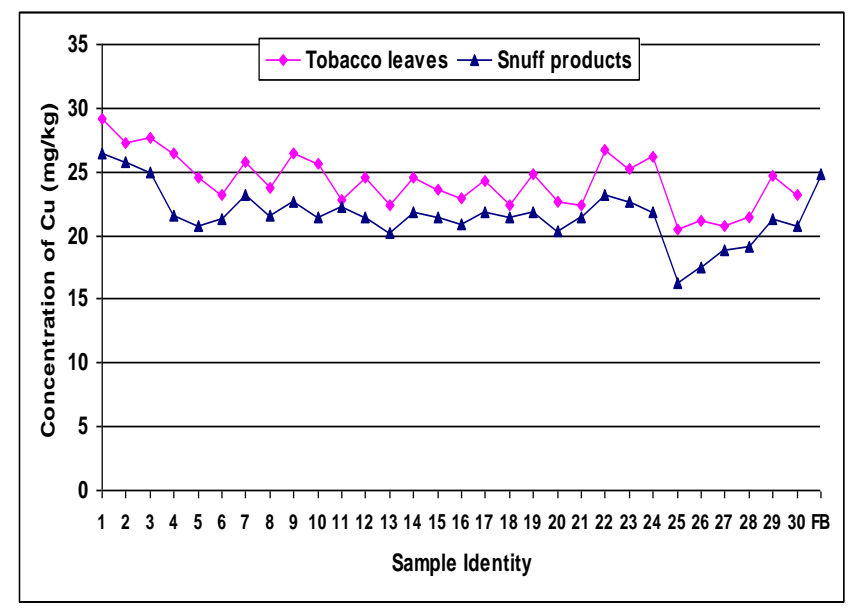

Fig 3. $\mathrm{Cu}$ concentrations in tobacco leaves and snuff samples

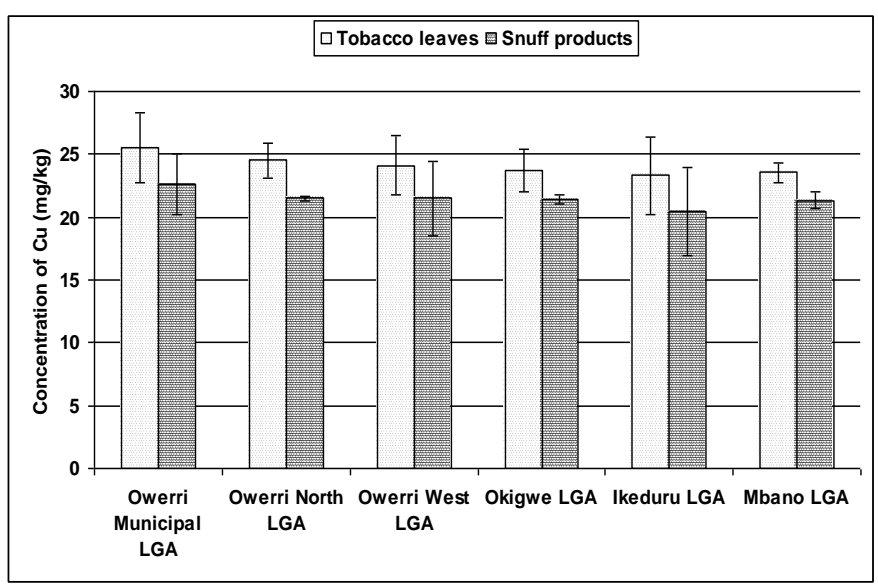

Fig 5. Comparison of $\mathrm{Cu}$ concentrations in tobacco leaves and snuffs

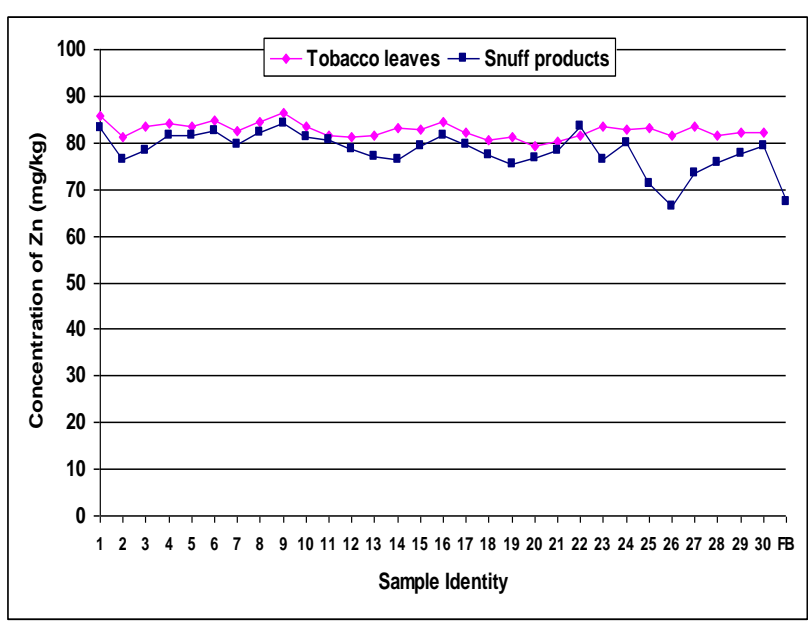

Fig 2. $\mathrm{Zn}$ concentrations in tobacco leaves and snuff samples

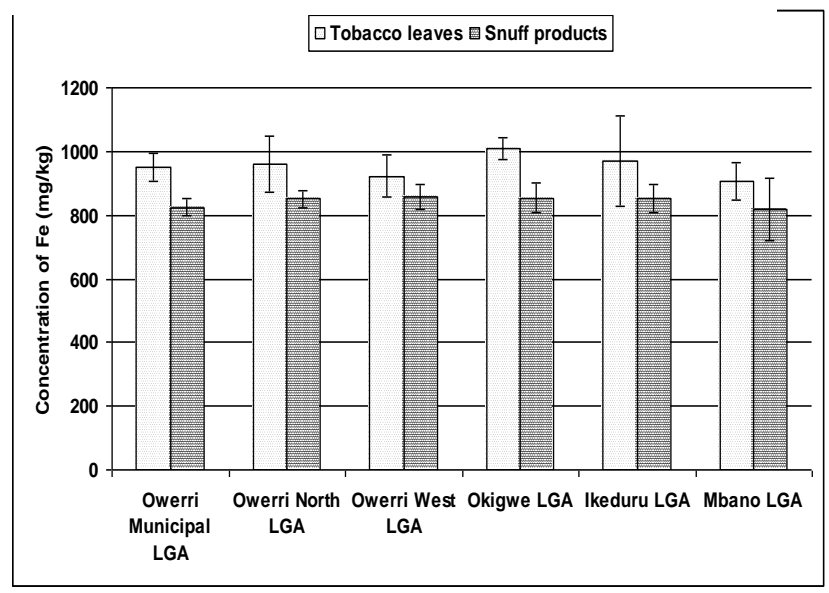

Fig 4. Comparison of Fe concentrations in tobacco leaves and snuffs

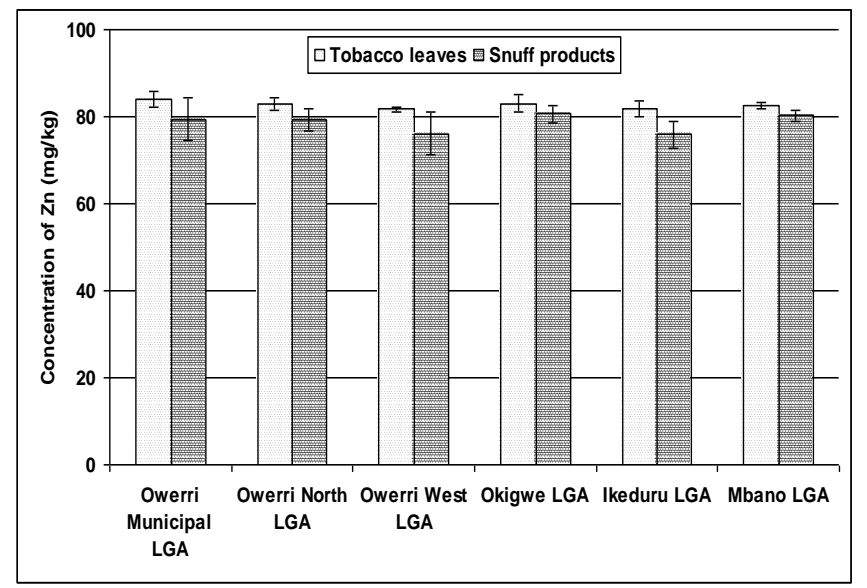

Fig 6. Comparison of $\mathrm{Zn}$ concentrations in tobacco leaves and 


\section{REFERENCES}

Abdel-Mageed, A.B and Oehme, F.W. (1990). A review of the biochemical roles, toxicity and interactions of zinc, copper and iron: I. Zinc. Veterinary and Human Toxicology 32 (1): 34-9.

Addo, M.A., Gbadago, J.K; Affum, H.A; Adom, T; Ahmed, K and Okley, G.M. (2008). Mineral profile of Ghanaian dried tobacco leaves and local snuff: A comparative study. Journal of Radioanalytical Nuclear Chemistry 277 (3): 51724.

Ajab, H; Yasmeen, S; Yaqub, A; Ajab, Z; Junaid, M; Siddique, M; Farooq, R; and Malik, S.A (2008). Evaluation of trace metals in tobacco of local and imported cigarette brands used in Pakistan by spectrophotometer through microwave digestion. Journal of Toxicological Sciences 33 (4): 415-20.

Ali, H., Pätzold, R and Brückner, H (2006). Determination of $\mathrm{L}$ - and D-amino acids in smokeless tobacco products and tobacco. Food Chemistry 99: 803-12.

Ayo-Yusuf, O.A., and Connolly, G.N (2011). Applying toxicological risk assessment principles to constituents of smokeless tobacco products: implications for product regulation. Tobacco Control 20: 53-7.

Baker, R.R; Massey, E.D and Smith, G (2004). An overview of the effects of tobacco ingredients on smoke chemistry and toxicity. Food Chemistry and Toxicology 42S: S53-S83.

Boffetta, P; Hecht, S; Gray, N; Gupta, P and Straif, K. (2008). Smokeless tobacco and cancer. Lancet Oncology 9: 667-75.

Brunnemann, K.D; Qi, J and Hoffmann, D (2002). Chemical profile of two types of oral snuff tobacco. Food and Chemical Toxicology 40: 1699-1703.

Chiba, M and Masironi, R. (1992). Toxic and trace elements in tobacco and tobacco smoke. Bulletin World Health Organisation 70 (2): 269-75.

Dhaware, D; Deshpande, A; Khandekar, R.N and Chowgule, R. (2009). Determination of toxic metals in Indian smokeless tobacco products. Scientific World Journal 14 (9): 11407.
Ebisike, K; Ayejuyo, O and Sonibara, J.A. (2004). Pollution impacts of cigarette consumption on indoor air quality in Nigeria. Journal Applied Sciences 4 (4): 623-29.

Elinder, C.G; Kjellstrom, T; Lind, B; Linnman, I; Piscator, M and Sundstedt, K (1983). Cadmium exposure from smoking cigarettes; variations with time and country where purchased. Environmental Research 32: 220-7.

Evangelou, M.W.H; Ebel, M and Shaeffer, A (2006). Evaluation of the effect of small organic acids on phytoextraction of $\mathrm{Cu}$ and $\mathrm{Pb}$ from soil with tobacco Nicotiana tabacum. Chemosphere 63: 996-1004.

Feng, B.J; Khyatti, M; Ben-Ayoub, W; Dahmoul, S; Ayad, M; Maachi, F; Bedadra, W; Abdoun, M. Mesli, S; Bakkali, H; Jalbout, M; Hamdi-Cherif, M; Boualga, K; Bouaouina, N; Chouchane, L; Benider, A; Ben-Ayed, F; Goldgar, D.E and Corbex, M. (2009). Cannabis, tobacco and domestic fumes intake are associated with nasopharyngeal carcinoma in North Africa. British Journal of Cancer 101: 1207- 12.

Fosmire, G.J. (1990). Zinc toxicity. American Journal Clinical Nutrition 51 (2): 225-7. Sastry, B.V.R. (1991). Placental toxicology: tobacco-smoke, abused drugs, multiple chemical interactions, and placental function. Reproduction, Fertility and Development 3: 355-72.

Galazyn-Sidorczuk, M; Brzóska, M.M and Moniuszko-Jakoniuk. J. (2008). Estimation of polish cigarettes contamination with cadmium and lead, and exposure to these metals via smoking. Environmental Monitoring and Assessment 137: 481-93.

Golia, E.E; Dimirkou, E.A and Mitsios, E.I.K. (2007). Accumulation of metals on tobacco leaves (primings) grown in an agricultural area in relation to soil. Bulletin Environmental Contamination Toxicology 79: 158-62.

Hammond, D and O'Connor, R.J (2008). Constituents in tobacco and smoke emissions from Canadian cigarettes. Tobacco Control 17 (Suppl I): i24-i31.

IARC. (1986). IARC Monographs on the Evaluation of the Carcinogenic Risk of Chemicals to Humans. Vol. 38. Tobacco Smoking. International Agency for Research on Cancer, Lyon. 
Iskander, F.Y. (1986). Egyptian and foreign cigarettes II. Determination of trace elements in tobacco, ash and wrapping paper. Journal of Radioanalytical and Nuclear Chemistry 97 (1): 107-12.

Iskander, F.Y. (1992). Multielement determination in Chinese cigarette brand. Journal of Radioanalytical and Nuclear Chemistry 159 (1): 105-10.

Iwegbue, C.M; Nwajei, G.E and Egu

avoen, O. (2009). Metal distribution in some brands of cigarette ash in Nigeria. Journal of Environmental Sciences and Engineering 51(2): 93-6.

Jung, M.C; Thornton, I and Chon, H.T. (1998). Arsenic, cadmium, copper, lead, and zinc concentrations in cigarettes produced in Korea and the United Kingdom. Environmental Technology 19 (2): 237-41.

Leffingwell, J.C., (1999). Basic chemical constituents of tobacco leaf and differences among tobacco types. In: Davis, D.L., Nielsen, M.T. (Eds.), Tobacco-production, Chemistry and Technology. Blackwell Science, Oxford, UK, pp. 265-284. Chapter 8a.

McNeill, A; Bedi, R; Islam, S; Alkhatib, M.N and West, R. (2006). Levels of toxins in oral tobacco products in the UK. Tobacco Control 15 (1): 647.

Mishra, U.C and Shaikh, G.N. (1983). Determination of trace element concentrations of Indian cigarette tobacco by instrumental neutron activation analysis. Journal of Radioanalytical Chemistry 78: 385-90.

Mishra, U.C and Shaikh, G.N. (1985). Determination of trace elements in total particulate matter of cigarette smoke by instrumental neutron activation analysis. Journal of Radioanalytical Chemistry 89: 545.

Mishra, U.C and Shaikh, G.N. (1986). Simultaneous multielement determination of chewing and snuff tobaccos used in India by INAA. Journal of Radioanalytical and Nuclear Chemistry 98: 297301 .

Mishra, U.C; Shaikh, G.N and Sadasivan, S. (1986). Trace elements in tobacco and tobacco smoke by X-ray fluorescence technique. Journal of
Radioanalytical and Nuclear Chemistry 102: 2735.

Mussalo-Rauhamaa, H; Salmela, S.S; Leppäen, A and Pyysalo, H. (1986). Cigarettes as a source of some trace and heavy metals and pesticides in man. Archives Environmental Health 41: 49-55.

Nada, A; Abdel-Wahab, M; Sroor, A; Abdel-Haleem, A.S and Abdel-Sabour, M.F (1999). Heavy metals and rare earth elements source-sink in some Egyptian cigarettes as determined by neutron activation analysis. Applied Radiation Isotopes 51: 131-6.

Nnorom, I.C; Osibanjo, O and Oji-Nnorom, C.G. (2005). Cadmium determination in cigarettes available in Nigeria. African Journal Biotechnology 4 (10): 1128-32.

Pakhale, S.S and Maru, G.B. (1998). Distribution of major and minor alkaloids in tobacco, mainstream and sidestream smoke of popular Indian smoking products. Food Chemistry and Toxicology 36: 1131-8.

Pappas, R.S; Polzin, G.M; Watson, C.H and Ashley, D.L. (2007). Cadmium, lead, and thallium in smoke particulate from counterfeit cigarettes compared to authentic US brands. Food Chemistry Toxicology 45: 202-9.

Pappas, R.S; Stanfill, S.B; Watson, C.H and Ashley, D.L. (2008). Analysis of toxic metals in commercial moist snuff and Alaskan iqmik. Journal of Analytical Toxicology 32 (4): 281-91.

Phillips, C.V and Heavner, K.K. (2009). Smokeless tobacco: the epidemiology and politics of harm. Biomarkers 14 (Suppl 1):79-84.

Roberts, D.L. (1998). Natural tobacco flavor. Recent Advances in Tobacco Science 14: 49- 81.

Russell, M.A; Russell, H; Jarvis, M., Devitt, G and Feyerabend, C. (1981). Nicotine intake by snuff users. British Medical Journal 283: 814-6.

Sandstead, H.H. (1982). Copper bioavailability and requirements. American Journal Clinical Nutrition 35 (4): 809-14.

Schneider, G and Krivan, V. (1993). Multi-elemental analysis of tobacco and smoke condensate by instrumental neutron activation analysis and atomic absorption spectrometry. International 
Journal Environmental Analytical Chemistry 53: $87-100$.

Shaikh, A.N; Khandekar, R.N; Anand, S.J.S. and Mishra, U.C. (1992). Determination of some toxic trace elements in Indian tobacco and its smoke. Journal Radioanalytical and Nuclear Chemistry 163: 348-53.

Shaikh, A.N; Negi, B.S and Sadasivan, S., (2002). Characterization of Indian cigarette tobacco and its smoke aerosol by nuclear and allied techniques. Journal of Radioanalytical and Nuclear Chemistry 253: 231-34.

Spiff, A.I; Horsfall, M. Jnr and Dairo, D.I. (1999). Determination of cadmium levels in cigarettes smoked in Nigeria. Journal Applied Science Environmental Management 2 (1): 43-5.

Stephens, W.E; Calder, A and Newton, J (2005). Source and health implications of high toxic metal concentrations in illicit tobacco products. Environmental Science Technology 39: 479-88.

Tso, T.C. (1990). Production, Physiology, and Biochemistry of Tobacco Plants. Beltsville, MD: IDEALS, 1990. http://www.longwood.edu/cleanva/ciglitterarticle .htm (accessed 24 Feb 2011).
Turnlund, J.R. (1988). Copper nutriture, bioavailability, and the influence of dietary factors. Journal of the American Dietetic Association 88 (3): 303-8.

Verma, S; Yadav, S and Singh, I. (2010). Trace metal concentration in different Indian tobacco products and related health implications. Food and Chemical Toxicology 48 (8-9): 2291-7.

WHO. (2004). Study Group on Tobacco Product Regulation. Guiding principles for the development of tobacco research and testing capacity and proposed protocols for the initiation of tobacco product testing, 2004.

WHO. (2011). Tobacco free initiative. Why tobacco is a public health priority. World Health Organization. http://www.who.int/tobacco/health_priority/en/in dex.html

Zawadska, $\quad \mathrm{T} ; \quad$ Brulinska-Ostrowska, $\quad \mathrm{E}$; Wojciechowska-Mazurek, M; Cwiek, $\mathrm{K}$ and Starska, K. (1989). Cadmium and lead levels in domestic and imported cigarettes. Rocz. Panstw. Zakl. Hig. 40 (2),145-52. 